\title{
TYPES OF HEGEMONIC CRISIS AND THE QUESTION OF THE EMERGENCE OF AUTHORITARIAN REGIMES IN THE SOUTH OF LATIN AMERICA*
}

\section{Francisco Panizza}

In this paper I will attempt to outline the theoretical framework of our research on the process of deterioration and collapse of the Uruguayan political system in the context of the emergence of other authoritarian regimes in the South of Latin America. For that purpose we shall: a) Criticize the economist analysis of the emergence of those regimes. b) Stress the importance of the distinction between the conditions of emergence of the regimes and their subsequent evolution. c) Propose the concept of hegemony as the most useful for the analysis of the conditions of emergence of those regimes. d) Introduce and discuss the concepts of hegemony and hegemonic crisis. e) Relate types of hegemony and of hegemonic crisis.

\section{The authoritarian regimes as the political form of a stage of dependent capitalist development}

I will start this section with a very broad comparison between the military-backed dictatorships of the South of Latin America and the fascist regimes of Europe in the second quarter of this century 1 . While the characterization of the so-called "Bureaucratic Authoritarian Regimes" ("B.A.") has been duiy criticized by several political scientists, we would like to point out some common elements between both types of regime which go beyond their wide range of political, social and economic differences. (For the definition of the B.A. as "fascists" see Briones, 1978; for a critique of the labelling see F. H. Cardoso, 1979).

a) Fascismo in Europe closed a period in which revolutionary changes seemed to be on the agenda in many western European countries. Similarly, in the late 1960s and early

\footnotetext{
" This paper is part of a Ph.D. research in progress on the "Crisis of the Uruguayan Political System." I want to thank E. Laclau, J. Forewaker, B. Jessop and Celi Pinto for their valvable comments.
} 
1970s, if not revolution, at least a process of deep political and economic change seemed to be emerging in several Latin American Countries. We shoul remember during that period the "Peruvian way" of Velasco Alvarado, the brief government of General J. J. Torres in Bolivia and above all, the return to power c/ Peronismo and the victory of the "Popular Unity" in Chile. By 1976 the dream was over and a network of repressive dictatorships ruled the region.

b) The traditional military coups in Latin America had not long-term political projects, but the Bureaucratic Authoritarian do have. Again, like the fascist regimes, they are attempting a deep reaticulation of social, political and economics relations in their societies. They are prepared for long periods of rule. As the Argentine's military have repeated time and again, the (the military) "have targets and not terms".

c) As in Europe in the late 1920s and 1930s the "Bureaucratic Authoritarian" regimes came to office at a time of economic crises in most Latin American countries. As fascism was related to the rule of financial capitalism, the B.A. were related to the requirements of Multinational Enterprises in Latin America.

d) Finally, the importance of this political phenomenon has resulted - as in the case of fascism - in massive out-flow of political analysis, reflection and controversy. However, while fascism as en explicit form of regime and ideology provided a common ground for anlysis, in the case of the Latin American so called bureaucratic authoritarian regimes, the common ground can not be taken for granted. Therefore the question is: can we regard the several military regimes of the region as individual examples of a certain type of political regime, and if so, on what grounds?

The common characterization of the regimes could be attempted through the accumulation of different descriptive features. So, it has been pointed out the the regimes emerged as a conservative reaction against former populist governments. That in those regimes, power was seized and held by the army as a corporation (as opposed to traditionally military "caudillos" like Stroesner or Perez Jimenez). That they strongly repressed popular organizations and even traditional political parties. That their social basis was an alliance between the military, the multinational enterprises and the State technobureaucracy and so on. 
This set of characteristics can be narrowed or extended according to the views of different scholars. However the major cbjection is not its validity but its descriptive status. For that reason we cannot know if they have a necessary relationship with their object of description (the regimes). So, for example, the 1973 Uruguayan coup was not launched against a populist regime but by the President of a conservative government (in alliance with the military) against Parliament. The distinction between the rule of the military as a corporation and the rule of charismatic military chiefs is not at all clear in $\mathrm{Pi}$ nochet's Chile. In the first stage of the military takeover by Ongania in Argentina in 1966 there was no repression of the trade union movement. In fact, some sort of understanding with at least some factions of the "Confederacion General del Trabajo" (CGT) was quite evident. But by far the most serious attempts to find a common ground between the military regimes have been related to their economic structures. Therefore those theories deserve further examination.

The common idea of the "economist" approaches to the study of the "Bureaucratic Authoritarian" regimes of Latin America is their attempt to establish a more or less direct relationship between the emergence of the regimes and the needs and patterns of development of peripheral capitalism. They can be divided and summarized in two basic theories: the theory of "superexploitation" and the theory of the "deepening of industrialization". The theory of "superexploitation" has been put forward e with certain differences among themselves - by scholars like R, M. Marini, A. Gunder Frank and N. Chossudovski. Their basic claim is that the "superexploitation" of the workers is a "necessary condition" for accumulation in the present stage of capitalist development in Latin America. In turn, authoritarianism is essential as a guarantee for capitalist accumulation in order to prevent the workers, through their trade unions and other class organizations, from resisting the process of superexploitation.

In more general terme Chossudovski (1979) claims that:

\author{
"While in the center capitalist countries \\ the post war policies of the Welfare \\ State not only activated the process of \\ circulation by sustaining high Levels of \\ consumer demand, they also supported the \\ formation of so-called 'human capital' \\ in the development of nigh technology
}


industries. In the peripherical social formations, on the other hand, the State supports the requirements of the Low-wage economy. The distribution and allocation of State expenditure, the underlying vacuum in the social sectors (e.g. health and education), the important allocations of military expenditure and repressive technology are functionally related to the requirements of the peripherical Labour process".

The adoption of repressive and violent methods of State control is therefore - according to him - an integral element of peripherical capitalism. Authoritarian and repressive regimes support and endorse the maintenance and development of low-wage economies.

It has been pointed out (Cardoso y Serra, 1978) that this theory falls into a fallacy common to most economist approaches, namely the tendency to exaggerate the importance of certain trends which do in fact appear in certain phases of this process, elevating them to the status of rigid "ironclad laws". Serra (1979) argues that even if it is true that there has been a fall in real wages in all authoritarian regimes, it remains true that, for capitalist accumulation, the fundamental issue is the rate of profit and not the rate of surplus value. Even if the former depends upon the latter - he points out - the dependence is not absolute, since the rate of profit is also a function of the output - capital ratio. Therefore other factors like capital savings, innovations and economies of scale are particularly important in a fast-growing process of industrializations.

In brief, according to Serra, even if the pattern of development based on the production of durable goods implies a tendency towards income concentration, political variables are also key factors in the shaping of the pattern of income distribution. As an empirical support for his argument Serra shows that in Brazil - between 1959 and 1970 - productivity increased by $75 \%$ in the industrial sector and the output-capital ratio, measured in current prices, increased approximately by $12 \%$ in the electrical and transportation industries in the same period.

The theory of the "deepening of industrialization" has been developed by G. O'Donnell in his early works on the so called "Bureaucratic Authoritarian Regimes" (O'Donnell, 1975, 1977, 
1979) The "deepening" is defined as the putting into place, through backward linkage, of the intermediate input and capital goods industries, once the "last stage" industries turning out consumption of final demand goods are established.

According to O'Donnell, the patterns of import-substitution -industrialization (ISI) in the more advanced countries of Latin America developed in a horizontal rather than a vertical way. The outcome of this trend was a growing bottleneck due to the need to import capital and intermediate goods in order to fulfil the demands of the industrial sector. The correspondence between the rise of the "Bureaucratic Authoritarian" regimes and the process of "deepening of industrialization" is based, in his view, on the requirement of political, economic and institutional stability in order to attract the mult national enterprises, the only ones able to carry on the task. The very possibility of social unrest must therefore be avoided by all means.

According to Hirschman (1971) this hypothesis by O'Donnell seems to have been influenced mainly by the policies of the Ongania regime in Argentina, where is was quite plausible that difficulties of deepening the industrial structure, and the need to do so by bringing in complex foreign technology through multinational firms, was experienced as a real problem before the first unsuccessful (Ongania) attempt in 1966 to implant an authoritarian regime. However, similar relations have not been found elsewhere. In countries like Chile and Uruguay the sheer size of their markets makes the idea of deepening industrialization highly unlikely. In the case of Brazil, Serra shows that the so called "deepening of industrialization" actually began in the late 1950s and early 1960s, that is, well before the 1964 military coup. He points out that as late as 1970 the rate of investment in the capital goods sector of the economy was lower than in 1962.

Beyond the critique of the economic assumptions themselves, their alleged relationship with the authoritarian regimes has also been called into question. I will summarize these objections as follows:

a) There is no evidence that the Latin American authoritarian regimes were established in order to pursue a specific strategy of capitalist development. As Hirschman points out: "What we have here therefore, is not an economic explanation of authoritarianism, but a political explanation of a turn in Brazilian economic development: prior existence of an authorita- 
rian regime facilitated the shaping of (a certain) economic policy..."

b) There is no evidence of the existence of a single specific structural economic difficulty (like the alleged exhaustion of the import-substitution-industrialization) underlaying the rise of authoritarianism in Latin America.

c) Even if a relationship between authoritarianism and a phase of dependent capitalist development could be established, the bureaucratic authoritarian regime cannot be posited as the result of a dependency on international monopoly capitalism. As has been pointed out (Cardoso, 1975), an identical form of state - capitalist and dependent, in the case of Latin America co-exist with a variety of political regimes. The economic policies implemented in Venezuela, Mexico, Argentina and Brazil in the late 1960s and early 1970s were quite similar but their political regimes were clearly listinct. Therefore, even if there is room for exploring the degree of "compatibility" between different forms of dependent capitalist development and types of regime, "o one to to one causal relationship between each stage of accumulation and a napprotriate type of political regime should be discarded" (Ibid.)

\section{The Conditions of Emergence and the Evolution of the Authoritarian regimes}

In my view a more accurate approach to the question of the characterization of the authoritarian regimes of the South of Latin America needs to go back to the distinction between the conditions of emergence of the regimes and their evolution. By resorting to this distinction we are not claiming originality. In fact the distinction is already present in O'Donnell's analysis of the Bureaucratic Authoritarian State. He claims that the B. A. derives, at the political level, from he perception by the dominant sectors of a "threat" to their rule. This "threat" was in his view a result of increasing activity and unrest in the "popular sector" and of the inability of the economic and political system to match its demands. O'Donnell labelled this situation of popular unrest, with an expression borrowed from Huntington, as "mass pretorianism". The intensity of the perception of this threat by the dominant sectors would affect according to O'Donnell - the evolution of the B.A.: The greater the perception of the "threat" the longer they would remain united. Othe scholars had also mentioned the question of the "threat" in the constitution of the B.A. F.H. Cardoso, (1975) 
develops a line of argument very close to O'Donnells's. He claims that: a) In several Latin American Countries the ruling classes were unable to control the political pressure launched by the workers and radicalized sectors of the middle classes. b) The military takeovers were a response to the crisis proviked by those struggles. c) In such circumstances the dominant sectors could not maintain their power without open military support. d) That the price to be paid forthis "help" depends on the extent of the political disintegration prior to military intervention..."

Finally A. Hirschman also singles out the existence of that "threat" (or the "great fear" as he calls it) from a politicoideological viewpoint: He remembers the reactions of the Latin American ruling groups to the Cuban revolution, the spread of guerrilla tactics on the left, and the determination of the U.S. to prevent a "second Cuba" as factors which - in his view contributed greatly to he installations of authoritarians regimes in Latin America.

I think that the above propositions about the emergence of the authoritarians regimes - and their connexions with their evolution - have not been fully developed and given the importance they deserve. Their consideration within a wider theoretical framework provides the basis for avoiding the mistake of explaining the establishment of the authoritarian regimes by the will to enforce a determinate economic policy. In turn, the concepts of hegemony and hegemonic crisis could provide the necessary theoretical framework for that analysis.

The concept of hegemony and the distinction between "normal" and "exceptional" forms of capitalist state.

The relationship between hegemony and democracy is the basis of the distinction that Poulantzas (1979) draws between "normal" and "exceptional" forms of capitalist state, i.e., between forms of capitalist state in which there are some institutionalised mechanisms for the election and control of government, and those others where the continuos rule of capital is secured through force and the suppresion of popular representation (Jessap 1978). Poulantzas claims that the transition from a "normal" to an "exceptional" form of capitalist state is always the result of an hegemonic crisis, through the converse is

* My italics. 
not necessarily true; a crisis does not always lead to an exceptional form. While an hegemonic force can articulate different social sectors into a unified subject under its leadership, an hegemonic crisis is characterised precisely by the desarticulation of this subject, and therefore by the inability of the dominant classes to gain the consent of the subordineted agents.

Poulantzas proposition is a rather generic one. It requires a more specific formulation, and therefore an inquiry into the concept of hegemony and its relation with different types of crisis. As is well known, the concept of hegemony is developed by Gramsci in his critique of the prevalling "economist" interpretations of fascism by the third International. Fascism was conceived, by the third International, as a general form of state domination corresponding to a critical stage of capitalist development, the phase of finance capital. As a passing and necessary episode of the crises of capitalism, fascism had to be the "last" political form of the dictatorship of the bourguoisie. Therefore there was no necessity, nor even room, for the distinction between different forms of bourgueois state. 2

In his critique to "economism" Gramsci rules out an immediate relationship between economic crisis and political crisis. $\mathrm{He}$ points out that the rupture of the equilibrium of political forces does not occur as the result of direct mechanical causes. It occurres "in the context of conflicts on a higher plane that the immediate world of the economy." He also rejects the idea of history as a development of necessary preordinated stages. A formal chronological conception of the "steps" of the historical process would, in the end, make political intervention irrelevant. 3 In this way he paves the way to the analysis of political conjunctures as a balance of forces at all levels which can only culminate in the sphere of hegemony and ethico-political relation.

"It is therefore necessary to combat economism not only in the theory of historiography, but also and especially in the theory and practice of politics. In this field the struggle can, and must be carried on, by developing the concept of hegemony as has been done in practice in the development of the theory of the political party." (Gramsci 1978, 165)

But, what does Gramsci mean by hegemony? As Ch. 
Mouffe (1979) has noted, the notion of hegemony within Lenin the marxist tradition was first introduced by Lenin. He argued for the necessity of an alliance between the workers and other social classes undder the leadership of the proletariat. Gramsci advanced Lenin's conception in two important aspects: a) $\mathrm{Ne}$ extended the field of application of the concept of hegemony beyond the revolutionary strategy of the proletaria: An hegemonic class is any ruling class who, being able to go beyond its own narrow corporate interests, is able to articulate in a certain equilibrium the interests and tendencias of the groups over which hegemony is excercised. b) With his conception of hegemony as "political, intellectual and moral leadership" Gramsci also went beyond the idea of a simple political alliance between social groups. According to him, the subjects of political action cannot be identified with social classes. Social classes, which exist at the economic level, are not duplicated at the political level; instead, different interclass subjects are created. (cf. Mouffe 1979)

In my view - at least analytically - three different levels can be distinguished in the concept of hegemony:

a) At its most embracing level hegemony is related to a certain "world view" or "conception of the world". This does not necessarily mean some sort of elaborate ideological system. Rather it refers to the field of "everyday philosophy" - common sense - as well as to the view of the given organization of society as a "natural fact". 4 Of course, at the same time, by definition, the boundaries of the "natural order" of society, set the limits of the social facts that can be thought of as "politicals". Gramsci stressed that these general ideas and opinions are not spontaneously born in eaach individual brain, but have a centre of formation, of irradiation, of dissemination, of persuasion - "a group of men, or a single individual man, which had developed them and presented them in the political form of current reality." (Gramsci, 1979, 192)

b) The above remark introduces us to the level of the social agents who produce the ideological practices. Political parties, the state and other social and political organizations form "collective wills" through the articulation and rearticulation in different ways of ideological principles and positionalities. According to Gramsci, through ideological struggles the hegemonic group present their development and expansion as being the development of "all the national energies". Therefore we are at the core of political practices: the result of the strug- 
gles depends on the relation of forces between rival hegemonic groups, relation which is in a process of continuos transformation. (Mouffe 1979). It is in this conjunctural relation of forces that political activity takes place and has an effect:

"The active politian is a creator, and iniciator, but he neither creates from nothing, nor does he move in the turbid vaid of his awn desires and dreams. He based himself on effective reality, but what is effective reality? Is it something static and immobile or is it not rather a relation of forces in continuos motion and shift of equilibrium? (Gramsci 1978, 172, my italics)

c) A political relation of forces is not just the result of an abstract ideological debate, it also requires a sytem of material practices and concessions between leading and subordinat groups. This is our third level of distinction in the analysis of the concept of hegemony. This level has been very much emphasised by Gramsci who stressed that a leading class should make sacrifices of an economic - corporate kind.5 How, the material basis can, in turn be related to the question of hegemon in 2 ways: a) to certain stages of economic development, and b) as a limit posed by the conditions of reproduction of the productive sytem.

Let us consider the first point. We have already rejected the attempt to establish a "one to one" relationship between a certain stage of capitalist development and a certain political regime.However this does not mean that no relationship at all can be established. As Poulantzas points out, the "stage" or period of economic development is important as it circumscribes the conjunctures of the classe struggle, and contributes to the emergence of political crises, "political crises which are not determined solely by the character of the period, and which may well occur in other periods toc." (Poulantzas 1979, 53) Let us consider the second point: how the material basis, in particular the conditions of reproduction of he system, poses a limit to hegemony. Laclau claims that a condition of possibility of an hegemonic policy is the existence of a distance or margin of variation between different levels of social reproduction. For example, he states that a model of capitalist accumulation which is only compatible with wages at a survival level, would make it impossible for the demands for better wages to be hegemonized by the discourse of power. (Laclau 1979) 


\section{Political Regimes}

The institutional forms by which the political struggles are settled and by which the "unstable equilibrium" between the material rewards of each social group is achieved constitue the political regime of a given social formation. So, for example, Przeworski defines capitalist democracy as "a system in which the institutionalization of surplus is the form in which a part of the product becomes witheld from the immediate producers and forms the basis for somewhat indeterminate struggles over the distribution of the product." He then points out that the indetermination of struggles over the realization of short-term material interests is a condition of hegemony since it leads to the organization of wage-earners as participants of struggles over distribution and allows their interest to be realised within some limits. (Przeworski 1977, quoted by Panitch 1981). Therefore a political regime comprises institutionalised forms by which the political struggles are processed, and institutionalised forms by which the economic rewards are distributed among the different sections of the population. Jessop refers to the former as forms of political representation, and to the latter as forms of state intervention. For him, an analysis of state forms presupposes definition of specific modes of articulation and disarticulation between representation and intervention. (Jessop, 1979)

\section{The subordinated agents.}

Hegemony is "leadership" and that mean that some social or political group leads the other. But in this specific issue a certain ambiguity can be spotted both in Gramsci and his commentators: In certain passages Gramsci seams to establish clearly hegemony as a relationship between the dominant fractions (whether bourgeoises or proletarians) in a given social formation:

"The methodological criterion on which our study must be based is the following: that the supremacy of a social group manifest in two ways, as "domination" and as "intellectual and moral leadership". A social group dominates antagonistic groups, which it tends to "liquidate" or to sujugate perhaps even by force, it leads kindred and allied groups." (Gramsci, 1978, 57)

However, in other passages of his Prison Notebooks Gramsci seems to regard hegemony as exercised (through different ways and practices) over the whole of society: 
"The previous ruling classes were assentially conservative in the sense that they did not tend to construct an organic passage from other classes into their own (...). The bourgeoisie poses itself as an organism in continuos movement, capable of absorbing the entire society, assimilating it to its own cultural and economic level." (Gramsci, 1978, 26) (my italics)

Jessop (1978) explicity states that in a democratic regime the power bloc should articulate and aggregate the interests of he dominated classes as well as its own interests. In turn Poulantzas, while defining the "exeptional form of state" as a form of state without hegemony, aknowledges the existence of an hegemonic relationship within the power bloc. However, in another passage he says that trade unionism and reformism are examples of the influence of bourgeois ideology over the working class, which implies that the dominant groups have the ability to lead the subordianted sectores of society. I think that this ambiguity can be clarified by relating it to the question of hegemonic crises.

\section{Hegemonic crises.}

Althusser wrote that the condition for a revolutionary crisis is that the accumulation of "circunstances" and "events" which constitute the crisis become fused in a "ruptural unity", "when they produce the result of the immense majority of the popular masses grouped in an assault on a regime which its ruling classes are unable to defend." (Althusser 1973) However not every hegemonic crisis is a revolutionary one and both Gramsci and Poulantzas stressed this point. Different types of (non revolutionary) hegemonic crises are analysed by both authors.

Gramsci claims that an organic crisis occurs when "incurable structural contradictions haver revealed themselves (reached maturity)." (Gramsci 1978, 78) Organic crises are crises of the ruling class hegemony and they manifest themselves as a crisis of representation. When this occurs, Gramsci said, social classes become detached from their traditional parties. In turn, this conflict between "represented" and "representatives" could have one of three different outcomes: 1) A changing of the men and programmes of the ruling classes, in order to regain the control that slipped from their hands. 2) The unification of the several factions and parties of the ruling classes under the banner of a single party. ${ }^{6} 3$ ) The emergence of a charisma- 
tic leader. This latter option occurs when no-group of the dominant classes has the strength for victory. Therefore organic crises are defined mainly as crises of (within) the power bloc.

But the hegemonic crisis could be focussed not (only) inside the power bloc, but between dominant and dominated forces. This is, in Gramsci's view, the case of "cesarism", a situation in which the forces in conflict balance each other in a "catastrophic manner": "that is to say, they balance each other in such a way that a continuation of the conflict can only terminate in their reciprocal destruction." (Gramsci 1978, 219)

The distinction between different types of crises is sharper in Poulantzas's works. Poulantzas distinguishes between a crisis produced by a situation of equilibrium (catastrophic or not) between the main forces in a social formation and a crisis at the power bloc. The first one is "a situation in which the two main antagonists are, according to the metaphor of the scale "in balance" (Poulantzas 1979, 60). A typical example of this sort of "crisis of equilibrium" is "bonapartism" where the dominant classes sacrifice their political domination to preserve their socio economic dominance. 7 In the crisis at the power bloc, internal contradictions between the dominant classes and class fractions are deepened and sharpened, as in the case of fascism:

"In the case of the growth of fascism and of fascism itself, do dominant class or class fraction seems able to impose its "leadership" on the other classes and fractions of the power bloc, whether by its own methods of political organization or through the parliamentary democratic state." (Poulantzas, 1979, 72)

Therefore we have two notions of an hegemonic relationship: a) The leadership of a group or fraction over its allies leadership as opposed to political domination (even by force) over antagonistic groups.

b) The ability of the dominant group to exercise a certain form of leadership even over the antagonistic groups. We have also two types of hegemonic of hegemonic crises: a) A crisis which is characterised mainly by conflict and disarticulation within the power bloc. b) A crisis of equilibrium between antagonic social forces. I think that both questions are related to different forms of articulation and rupture of a given society. 


\section{Hegemony: rupture and "transformism".}

The ability of the dominant groups to lead, through specific practices even the subordinated sectors of society, was very present in Italian history since the second part of the XIX century. This process come to be known as "transformism" 8 : For Gramsci transformism is one of the historical forms of "revolution-restoration" or "passive revolution". In his analysis of the function of Piedmonte in the Italian "Risorçimento" Gramsci relatas the concept of "passiva revolution" to the "war of position". He asks himself: "Can the concept of "passive revolution" (...) be related to the concept of "war of position" in contrast to "war of maneuvre"? As an answer he suggests the posibility that there could be entire historical periods in which the two concepts should be considered identical, until the point at which the "war of position" once again becomes a "war of maneuvre". (Gramsci, 1978, 109)

"Transformism" and "passiva revolution" are, thus, types of "war of position". But the concept of "war of position" has a much broader scope in Gramsci's thought. It is related to the structures of western societies as oppossed to the Russian pre-revolutionary society. While in Russia the state was everything - Gramsci said - in the west "civil society" has become a very complex structure and one which is resistant to the "catastrophic incursions" of the immediate economic elements (crisis, depresions etc). Therefore, the "war of position" is constituted by the "whole organizational structure and industrial system of society." As a consequence, while in the "war of maneuvres" a frontal attack of state structures (like the Russian insurrection) is possible, in the "war of position" a process of disarticulation/rearticulation of the positionalities of civil society is required before the seizure of power. ${ }^{9}$ Which is the specific characteristic of "transformism"/"passive revolution"? The answer is that "transformism"/"passive revolution" is the "war of position" of the dominant classes. It is a process by which the dominant sectors in society attempt to prevent the formation of an antagonic popular subject through a system of absorption and neturalisation of their interests in a selective way. (Mouffe 1979) Christine Buci Glucksman points out that passive revolution becomes a potential tendency intrinsic to every transitional process. For, to a certain extent, every passive revolution develops a "conservatism or moderate reformism" which breaks up the free political dialectic of class contradiction and neutralises and channels popular initiative. (B. Glucksman 1979) Therefore transformism/passive revolution requi- 
res some form of "corporate sacrifices" and concessions by the ruling sectors, not only in favour of their allies but also in favour of the dominanted sectors It also requires an active political and ideological intervention over those dominated sectors in order to prevent the constitution of a unfied antagonistic subject. That is to say transformism/passive revolution" requires a more interventionist state.

Another type of hegemony is however possible. An hegemonic relationship does not deals with preconstitutes subjects: What is astake in hegemony is the constitution itself of the subjects, and political and ideological struggles are struggles for that constitution. Subjects are constituted around the definition of political struggle (about class, race, religion, nation etc.), around forms of organization (different types of political parties, movements, personalities) and around forms of regulation of the struggles (state intervention and control over trade unions, cultural and educational institutions etc.) Hegemony is the principle of constitution of the social agents. (Laclau 1979)

Now, the result of the hegemonic struggle need not be a selective and subordiante incorporation of the dominated redors of the population. Instead it could be the constitution of a unified antagonic subject.

In every historical conjuncture there is a plurality of antagonisms without a necessary, paradigmantic relationship. Their articulation is the outcome of a "war of position" which produces the hegemonic form of society. (Laclau 1979) When those antagonisms are articulated around a unified popular subject they constitue a contradictory alternative to the power bloc. Society thus becomes divided between "dominant" and a "dominated" political subjects.

It is now clear that the ambiguity of the concept of hegemony is not accidental. It reflects different forms of hegemonic articul in different social formations. When a society is divided in antagonic posisionalities, hegemony is a relationship at the interior of each antagonic subject: the dominant classes (the power: bloc) and the people. In each of those subjects the circulation of hegemony is exercised through leadership and "corporate concessions". In turn the crisis which results from the constitution of a unified, antagonic popular subject is a crisis between the two blocs.

On the other hand, the "transformist" process leads to an 
attempt to establish an ever enlarged hegemony over the entire society. Its success presupposses that no antagonic subjects are constituted. This is not a necessary judgment over its proressive or conservative character. As Gramsci stressed in his analysis of the italian "Risorgimento" this "passive transition" simultaneously embraced in a highly contradictory fahion, both (bourgeois) revolutionary elements and elements of restoration (compromises with the former dominant strata). But, by its very contradictory nature, the continuos attempt to absorb and integrate (transform) the interests of the dominated classes could upset the unstable equilibrium within the power bloc when this occurs the transformist process reaches its limits. 10 The equilibrium of the power bloc then crumbles, and a crisis between the dominant classes and class fractions is the result. This does not mean that during a crisis of transformism there is no struggle between antagonic forces, but just that - in Poulantzas' words - the split between the dominant classes and class fractions is the principal aspect of the crisis ("the principal aspect of the principal contradiction").

\section{Conclusion: "threats" and "hegemonic crises".}

The passage from a "normal" form of state to an "exceptional" one is produced by an hegemonic crisis. It is this kind of crisis which O'Donnell, Cardoso, Hirschman et. al. are speaking of when they mention the "popular threat" or the "inability of the dominant sectors to control social struggle" in the historical conjuncture of the appearance of the Bureaucratic Authoritarian regimes. But those crises are of very different types: There did the "threat" come from in cach case? How was it perceived by the dominant sectors? Which was the role of the state in the development of the crises?

It is clear that those questions have different answers in each historical case. So, for example, in Chile 1973 the "threat" came from the State itself, and the conflict was between two antagonic blocs. The image of a country divided into "halves" is present in every account of the period. In Uruguay, in the same year, there was no visible "threat" at the time of the "coup d'etat" (even if there had been one before). The coup developed as a prolongued conflict between a right wing President (allied with the military) and a parliament dominated by conservative and moderate forces. A process of class struggle had been under way, but by the time of the coup the popular sector was in a defensive, subordinate position. In Poulantzas terms the coup d'etat did not correspond to a political crisis of 


\section{equiliorium: It was the final stage of the collapse of (probably) the most succesful transformist project in Latin America.}

\section{FOOTNOTES}

1 The military-backed regimes of the South of Latin America has been Labelled "Brureaucratic Authoritarian Regimes" ("B.A."). Beyond the merits or accuracy of the Label - produced by G. O'Donnell - It is broadly used in political literature, and therefore it is a useful point of reference.

2 "Fascism grows organically out of bourgeois democracy. The process of passing from bourgeois dictatorship to open forms of repression is the essence of bourgeois democracy (...) between fascism and bourgeois democracy there is only a difference of degree (...) fascis mis not a new form of government." (Malunisky's report to the Xth plenum of the third international, quotec by Poulantzas, 1979, 58)

3 "For the conception upon which the aversion (to compromises) is based can only be the iron conviction that there exists objective laws of historical development similar in kind to natural laws, together with the belief in a predetermined teleology like that of a religion: since favorable conditions are inevitable going to appear, and since these, in a rather nysterious way, will bring about palingenetic events, it is evident that any deliberate initiative tending to predispose and plan these conditions is notonly useless but even harmful." (Gramsci, 1978, 158)

4 "One of the commonest totews is the belief about everything that exists, that it is "natural", that it should exist, that it could not/ouherwise than exist..." (Gramsci 1978, 157)

5 "... for though hegemony is ethical-political, it must also be economic, must necessarily be based on the decisive function exercised by the leading group in the decisive nucleus of economic activity." (Gramsci 1978, 161)

6 "It represents the fusion of an entire social class under a single leadership which alone is held to be capable of solving an overriding problem of its existence and of fending off a mortal danger" (Gramsci 1978, 211)

7 While for Gramsci fascism was a result of a "catastrophic" crisis of equilibrium, Poulantzas rejects his viowpoint. Poulantzas points out that by the time fascism came to power the working class had olready been defeated, and the bourgeoisie did not have to paxy with this defeat with any "catastrophic equilibrium".

8 "Indeed one might say that he entire state life of Italy from 1848 onwards has been characterised by transformism-in other words by the formation of an ever more extensiv ruling class (...) The formation of this class involved the gradual but continuos absorption, achiave by methods wich varied in their effectiveness, of the active elements produced by allied groups - and even of those which came from antagonistic groups and seened irreconciliably hostile. (Gramsci, 1978, 59)

9 In the words of Ch. Mouffe: "The war of position is the process of ideological struggle by means of which the the two fundamental classes try to appropriate the non class elements in order to integrate then with the ideological system, which articules itself around their respective hegemonic principles." (Ch. Mouffe 108)

10 Through state intervention and control, in the economy, in industrial relations, in education and cultural production, the demands of the popular sector is integrated to the discourse of the dominant sectors. However this does not mean that the state works as a "rational agent" of a process in which every concession to the dominanted classes benefits the ruling sector ("in the last instance"). By this very process of intervention the state becomes a field of struggles, and the outcome could be against the interests of some fractions of the power bloc. 


\section{REFERENCES}

1 Althusser Louis, "For Marx", Verso Editions, London 1973. Briones, Alvaro. "Economia y politica del fascismo dependiento - S. XXI - Mexico 1978. Buci Glucksman Christine," State, Transition and Passive Revolution in Mouffe Ch. (ed) "Gramsci \& Marsist Theory" RKP, London, 1979.

2 Buci Glucksman Christine, "Sobre o Conceito de Crise do Estado e sua Historia." In Poulantzas". (ed) "O Estado em Crise", Graal, Rio de Janeiro 1977.

3 Cardoso F. M. "Autoritarismo e Democratização", Paz e Terra, Rio de Janeiro 1975.

4 - "On the characterization of Authoritarian Regimes in Latin America" in Collier D. (ed), "The New Authoritarianism in Latin America." Princeton Univ. Press, Princeton, New Jersey 1979.

5 Cardoso F. M. \& Serra J., "Las Desventuras de la Dialectica de la Dependencia", Revista Mexicana de Sociologia (numero extraordianri 1978.

6 Chossudovski M. "Trasnationalization and the Development of Peripheral Capitalism", Research paper No. 7903, Faculty of Social Sciences, Department of Economics, University of Ottawa.

7 Gramsci Antonio, "Selection from Prison Motebooks", Lawrence and Wishart, London 1978.

8 Hirschman, Albert O., "The Turn of Authoritarianism in Latin America and the Search for its Economic Determinants", in Collier C. (ed) "The New..."

9 Jessop Bob, "Capitalism and Democracy: The Rest Political Shell? Littlejohn G. et al (ed.), "Power and the State". Croom Helm, London 1976.

10 Laclau E. "Tosis acerca de la Forma Hegemonia de la Politica." mimeo, Mexico 1979.

11 . "Politica e Ideologia na Teoria Marxista", Paz e Terra, Rio de Janeiro, 1979.

12 Marini Rui Mario, "Las Razones del Maodesarrollismo", en Revista Mexicana de Sociologia, (Numero Extraordinário) 1978.

13 Mouffe Chantal, "Hegemony and Ideology in Gramsci" in Mouffe (ed) "Gramsci...".

14 Mouffe Ch. and Showstack Sasson A. "Gramsci in France and Italy, A review of the literature." in "Economy and Society" feb. 1977.

15 O'Donnell G. "Corporatism and the Question of the State" in Mailoy M. (ed), "Authoritarianism and Corporatism in Latin America" University of Pittsburg Press, Pittsburg 1977.

16 O'Donnell G. "Reflexiones Sobre las Tendencias Generales de Cambio en el Estado Burocratico Autoritario". Documento CEDES/G.E. CLACSO No. 1, CEDES, Buenos Aires 1975.

17 O'Donnell G. "Tensions in the Bureaucratic Authoritarian State and the Question of Democracy", in D. Collier (ed) "The New...".

18 Panitch Leo, "The Limits of Corporatism" in New Left Review 125, jan/feb. 1981.

19 Poulantzas M. "Fascism and Dictatorship" Verso Editions, London 1978.

20 —. "State Power, Socialism". Verso Editions, London 1980.

21 Serra Jose, "As Desventuras do Economicismo: Tres teses equivocadas sobre a conexão entre Autoritarismo e Desenvolvimento", in DADOS 20, Rio de Janeiro 1979.

\section{Universidade de Colchester Uk}

